\title{
Analysis on Problems and Measures of Ideological and Political Education for College Students in New Media Environment
}

\author{
Yujia Lei \\ Southwest University of Science and Technology, Mianyang Sichuan, 621010, China
}

Keywords: new media environment; college students; ideological and political education; problems

\begin{abstract}
Ideological and political education is one of key contents of college student education. The favorable ideological and political education has positive function and significance for college students to form the correct life outlook and values. In the new media environment, traditional ideological and political education form also changes fundamentally. But seeing from current situation, many problems and defects still exist in the ideological and political education of college students. Based on deeply analyzing the features of ideological and political education of college students, this paper states and analyzes the effective measures to improve the quality of ideological and political education in the new media environment.
\end{abstract}

\section{Introduction}

Ideological and political education is an important component of higher education. The universities will provide large quantities of professional talents for the state. So, college education quality plays a very important role for social development. In the face of fierce talent competition situation, all-round improvement of comprehensive quality has become the theme of education. It is also the case in college education. Ideological and political education is a key content of college student education, and also the critical factor promoting all-round development of college students. The emergence and development of new media technology brings a brand-new reform opportunity for ideological and political education. In such situation, it is required to deeply analyze main problems in ideological and political education for college students and propose the targeted improvement measures in the new media environment in order to facilitate all-round improvement of comprehensive quality of college students.

\section{Significance of ideological and political education for college students in new media environment}

\subsection{Positive function for adapting to the development trend of quality-oriented education}

Under the traditional education mode, exam-oriented education excessively emphasizes students' exam results and pays little attention to promotion and development of students' comprehensive quality. For college students in the stage where their various abilities are forming, this teaching mode should not be advocated ${ }^{[1]}$. College students' world outlook and values still do not form. Ideological and political education plays a great role for cultivating students' life outlook and values. Stressing improvement of ideological and political education quality in college education can change the situation in which students passively receive knowledge, and let college students develop good thinking and behavior habits in the learning process so that they can better learn and gain certain sense of participation and achievement. This is very beneficial for students to form emotion and attitude. Besides, ideological and political education well conforms to essential requirements of quality-oriented education and reaches the purpose of promoting students' all-round development. 


\subsection{Positive significance for improving college students' comprehensive quality}

Influenced by traditional education idea, teachers deem improvement of students' exam results as the main teaching objective, and the design and implementation of all teaching programs focus on this objective. Furthermore, when universities evaluate teachers' teaching quality, students' learning and exam results play a decisive role for the evaluation result. Thus, due to the joint influence of multiple factors, teachers completely adopt exam-oriented education mode, ignore cultivation of students' learning ability and comprehensive quality and pay little attention to students' ideological and political education. The college stage is an important stage for students, and also the key stage for them to cultivate abilities and habits. The favorable ideological and political education is an important guarantee for students' future study and development. Valuing ideological and political education in college education can change the defects of traditional teaching mode, help students cultivate correct life outlook and values, and make students concentrate on classroom to better learn knowledge and to lay a solid foundation for all-round improvement of their comprehensive quality.

\subsection{Important influence on promoting formation of college students' world outlook and life outlook}

Due to the deep-rooted influence of exam-oriented education idea, teachers generally adopt the traditional teaching mode in college teaching process. Cramming education goes through the whole learning process of students. Ideological and political education is also of no exception. In current education development situation, such teaching mode cannot adapt to basic requirements of quality-oriented education and is not good for cultivating and promoting students' comprehensive quality ${ }^{[2]}$. College students are in the key stage where their world outlook and comprehensive quality develop in an all-round way, and their abilities do not form completely. Such single and boring teaching mode is difficult to motivate students' learning interest. As times goes on, college students will form certain boredom, which is very adverse to implementation of follow-up teaching. Active application of new media technology in ideological and political education can to large extent change such boring teaching form, effectively motivate students' learning enthusiasm, stimulate their learning interest and make them develop good learning habits so as to facilitate continuous improvement of ideological and political education quality.

\section{Main problems of ideological and political education in new media environment}

In current new media environment, traditional ideological and political teaching cannot adapt to the mainstream trend of era development, and many problems and defects are exposed gradually. Thus, before in-depth analysis of effective countermeasures for college students' ideological and political education, it is required to firstly confirm the outstanding problems in the teaching process so as to make the application of teaching measures more targeted and thus improve teaching quality. Generally speaking, the following problems mainly exist in ideological and political education under the new media environment:

\subsection{Traditional teaching concept pays insufficient attention to college students' ideological and political education}

Although cultivating college students' innovation ability and practice spirit has been the basic requirement of teaching program and quality-oriented education, teachers do not pay mush attention to it in practical college teaching process. College students' ideological and political education is also of no exception. Since teacher's teaching quality is uneven, different results will appear in the process of understanding students' quality cultivation. College students are faced with severe employment pressure and fierce talent competition situation. Only those with excellent professional quality can stand out in the fierce competitions. So in order to better facilitate and promote employment quality, colleges mostly concentrate on professional course study and ignore the subject of ideology and politics. Teachers usually slight over ideological and political education in the teaching process, and 
do not formulate the scientific and thorough teaching program. Thus, it is very hard to guarantee ideological and political teaching quality.

\subsection{College students lack learning interest and enthusiasm}

Favorable ideological and political quality is an important ability for students to learn professional knowledge well and improve comprehensive quality. in the learning process, teachers should effectively facilitate students to give play to innovation ability and cultivate their ideological and political quality. First of all, it is required to cultivate students' interest in learning ideological and political knowledge. But it is a pity that, current ideological and political teaching mostly rests on traditional teaching mode, and lacks teaching mode innovation and upgrading. Students will feel dull and boring in the learning process, and may easily lose learning interest ${ }^{[3]}$. In addition, students are generally in the passive status in the learning process, and the teacher is the class dominator. Students' learning initiative cannot be effectively mobilized. So, it is difficult to effectively cultivate college students' ideological and political quality.

\subsection{Traditional teaching mode cannot adapt to the development of new media environment}

In ideological and political teaching practice, traditional teaching mode is always based on exam-oriented education. The teaching quality is completely measured by depending on students' exam results. Thus, colleges deem improvement of students' exam results as the key teaching point,. However, such exam-oriented education mode is very adverse to cultivating students' ideological and political quality. Because the course of ideological and political education is a main subject of examination, college teachers adopt creaming education method, and replace understanding with simple recitation. The teaching mode is single, and students' learning ability cultivation is totally ignored. Moreover, such traditional exam-oriented education mode cannot adapt to the development trend of new environment and goes against exertion of students' innovation ability.

\section{Effective measures to promote college students' ideological and political education quality in new media environment}

Based on the above analysis, we can see that solving the problems of ideological and political education has become a problem to be urgently resolved. But, it is a relatively long process to resolve these problems, and a series of effective measures are required to reach the expected effect. To be specific, the following measures may be taken:

\subsection{To conduct optimal design of college ideological and political course by new media technology}

In college ideological and political teaching practice, reasonable optimization of course design is an important precondition of improving teaching quality. To reach course capacity maximization and course effect optimization within the limited classroom time, it is required to carefully carry out course design and improve the quality of classroom teaching. Thus, based on studying teaching materials and course objective, college ideological and political teachers should actively apply new media technology to survey students' knowledge level and comprehensive ability objectively and effectively, organically combine the two and give play to the functions of classroom teaching in the aspects of detailing textbook contents and deepening teaching effect ${ }^{[4]}$.

\subsection{To actively apply new media technology to promote teaching quality}

The rapid development of information technology changes many traditional industries and fields, and the very ideal application effect has been gained. If new media technology can be applied in college ideological and political teaching process, the teaching quality will improve greatly. New media teaching has advancement and operability. The abundant teaching resources make multimedia become an essential means of classroom teaching. In order to improve classroom teaching effect, it is required to start from the effective application of new media. The new media teaching advantages are 
obvious to all, but effective connection with teaching is easily ignored. Subject resources of modern new media technology bring numerous advantages for college ideological and political teaching, but there are also many disputes. The key lies in the combination mode of traditional teaching and new media teaching. In the previous classroom teaching practice, many teachers do not consider the value and significance of new media when applying it, and often adopt some formalistic teaching methods so that the new media becomes a fresh thing without practical significance. The best application mode is to regard new media technology as the means to break through the key and difficult points in teaching. Multimedia image, audio and animation may be used for teaching. Teachers should apply the brand-new media technology form for specific operation and teaching, and students solve specific problems in the course through practical operation. This can enrich classroom form and promote effective improvement of college ideological and political teaching quality.

\subsection{To cultivate students' autonomous learning ability by new media technology}

New media environment is an inexorable trend of era development, and its application in educational field is also an important condition for teaching form to closely follow era development. In college ideological and political teaching process, teaching mode reform is a very important link. Influenced by traditional teaching mode, cramming education mode is always adopted for college ideological and political teaching. The whole classroom teaching process is dominated by the teacher, and students are in the passive position. This is very disadvantageous for motivating and exerting students' learning initiative. So, teachers should actively apply new media technology, improve disadvantages of traditional teaching mode, innovate for classroom teaching mode and stimulate students' learning interest ${ }^{[5]}$. For example, teachers may carry out ideological and political teaching through new media to motivate their learning interest and cultivate their autonomous learning ability. The application of new media technology aims to weaken teacher's leading role, let students conduct effective exploration and solve practical problems. To achieve this objective, we should make overall planning in the aspects of ideological and political course planning, question design and effective guidance. Thus, the favorable teaching program and evaluation system should be set in routine teaching, and the feasibility of new media technology is measured by learning objective achievement and learning effect realization so as to promote teaching effect and help college students develop better.

\section{Conclusion}

In conclusion, certain problems exist in college ideological and political education under new media environment. In a bid to effectively solve these problems, a series of effective measures should be taken in time. New media technology should be applied to continuously conduct innovation and improvement of ideological and political education mode and to facilitate continuous improvement of teaching quality.

\section{Acknowledgement}

This paper is supported by SWUST 2017 student education management and reform research project, project No.: 17sxb193; project title: Study on College Students' Political Identification Cultivation in New Media Environment.

\section{References}

[1] Gao Heng, Study on Ideological and Political Education for College Students under New Media View, Journal of Anhui University of Technology (Social Science), 2016(5):111-112.

[2] Tang Xuemei, Wei Xingge, Wang Weiqiang, Innovation Research on Ideological and Political Education for College Students in New Media Era, The Guide of Science \& Education, 2017(10):76-77. 
[3] Yang Qingshan, Ma Yuntian, Study on Speaking Right of Ideological and Political Education for College Students in New Media Era, School Party Building and Ideological Education, 2017(14):62-63,66.

[4] Liu Bomin, Exploration on Trend of Ideological and Political Education for College Students in New Media Background, Journal of Inner Mongolia Normal University (Educational Science), 2015(1):42-44.

[5] Yang Xuezhi, On Microblog Carrier of Ideological and Political Education for College Students in New Media Environment, Decision-making Forum - Collected Papers for Academic Seminar of Scientific Decision-making Theories and Methods, Hebei University of Water Resources and Electric Engineering, 2015:61-61. 